"Енергетика і автоматика", №3, 2020 р.

UDC 674.047

DOI 10.31548/energiya2020.03.026

\title{
MATHEMATICAL SUPPORT OF ENERGY EFFICIENCY AND COMFORTABLE CONDITIONS IN HIGHER EDUCATION INSTITUTIONS OF \\ UKRAINE
}

\author{
N. G. Batechko, Doctor of Pedagogical Sciences, Academician of the UAA \\ O. V. Shelimanova, Candidates of Technical Sciences, Associate Professors
}

S.V. Shostak, Candidates of Technical Sciences, Associate Professors

National University of Life and Environmental sciences of Ukraine

E-mail: batechko_n_@ukr.net

\begin{abstract}
The relevance of increasing the energy efficiency in buildings of domestic higher educational institutions is determined not only by the need to save energy resources, but also by the fact that such "green campuses" can become the basis for the formation of an ecological and energy efficient lifestyle for today's youth. An integrated approach to the selection of energy-saving measures in a building requires the models of thermal comfort which take into account the intensity of human activity, the type of clothing, the speed of air movement in the room, relative humidity and the like.

The purpose of this study is to improve the efficiency of the energy system of campus buildings by taking into account the interaction of energy sources, the heating system, the thermal properties of the enclosing structures and the standardized parameters of the indoor microclimate.

Along with an integrated approach to the problem under study, taking into account the necessary comprehensive analysis of energy-saving measures in the system "heat source - enclosing structures - external parameters", attention should be paid to the indoor climate and the problem of meeting human needs for thermal comfort.

With the help of a miniature temperature datalogger $R C-1 B$, a round-the-clock monitoring of temperatures was carried out in some rooms of the educational building No. 8 of National University of Life and Environmental Sciences of Ukraine during the heating season.

The analysis of the experimental data shows that despite the improvement of the thermal accumulative properties of the outer fencing of the building after the implementation of thermal modernization work, the temperatures in the room do not always correspond to the norm.

Thus, when implementing energy-saving measures, it is impossible to violate the conditions of comfort in rooms in which thermal equilibrium is maintained in the human body and there is no tension in its thermoregulation system.
\end{abstract}

Key words: energy efficiency of the building, multifactor mathematical model, thermal comfort 
"Енергетика і автоматика", №3, 2020 р.

The relevance. The problem of energy efficiency has recently become global, but it is especially relevant for Ukraine, where these issues are closely related to ensuring the energy independence of the state.

The acuteness of the problem of energy supply for domestic higher education institutions (HEIs) is associated with limited budgetary financing of expenditures (primarily for utilities, among which the most significant are the costs of energy supply) and low energy efficiency of buildings of HEIs.

The relevance of improving the energy efficiency in buildings of domestic higher educational institutions is determined not only by the need to save energy resources, but also by the fact that such "green campuses" can become the basis for the formation of an ecological and energy efficient lifestyle for modern youth [1].

Analysis of recent research and publications. General principles for assessing the thermal energy efficiency of buildings lay in the establishment of a set of estimated indicators characterizing the unit energy consumption for heating and ventilation or air conditioning of the premises.

In N. Mkhitaryan's works [3] the need for a comprehensive analysis of energy-saving measures in a building is substantiated, as far as maximizing one of them can contribute to maximizing the other. The author used a systematic approach to the building, taking into account the heat source, enclosing structures and the influence of the external climate. However, this study did not pay sufficient attention to the indoor microclimate and the issue of meeting human needs for thermal comfort.

The basic principles of considering a building as a unified energy system are presented in the work of A. Tabunshchykov [2], but the author did not take into account the influence of a heat source on energy exchange processes.

It was proposed to choose certain energy-saving measures for already constructed buildings [4] on the basis of a unified energy model of the building, taking into account the influence of the environment and determining the thermal characteristics of the building envelope. 
"Енергетика і автоматика", №3, 2020 р.

When choosing an investment project for reduction of the energy consumption of buildings, various researchers used approaches based both on linear models and on the application of the theory of fuzzy sets [5].

However, during the analysis and design of complex systems "source of heat building" in these works, such an important aspect as a person was left without attention. An integrated approach to the selection of energy-saving measures in a building requires the models of thermal comfort which take into account the intensity of human activity, the type of clothing, the speed of air movement in the room, relative humidity and the like.

The purpose of the study is to improve the efficiency of the energy system of the campus buildings by taking into account the interaction of energy sources, heating systems, heat-shielding properties of enclosing structures and standardized parameters of the microclimate of premises.

Materials and methods of research. Despite the fact that the studied system for ensuring the energy efficiency of campus buildings is multi-parameter, for the process of its modeling it is advisable to use a multivariate mathematical model and a procedure for constructing multivariate linear regression equations, with the help of which it is possible to reflect rather accurately the change in the volume of fuel or energy consumption on the object under study depending on numerous factors which significantly affect this process. The use of multivariate mathematical models in the study of the process of ensuring energy efficiency of campus buildings will allow obtaining much more accurate and substantiated results of monitoring the energy efficiency on the objects under study and predicting its increase.

The experimental studies will confirm the legitimacy of the application of the methods of self-organization of mathematical models by taking into account the interaction of energy sources, the heating system, heat-shielding properties of building envelopes and standardized parameters of the microclimate of the premises.

Research results and their discussion. Along with an integrated approach to the problem under study, taking into account the necessary comprehensive analysis of energysaving measures in the system "heat source - enclosing structures - external parameters", 
"Енергетика і автоматика", №3, 2020 р.

attention should be paid to the indoor climate and the problem of meeting human needs for thermal comfort.

In some rooms of the educational building No. 8, during the heating season, roundthe-clock temperature monitoring was carried out. A miniature $\mathrm{RC}-1$ temperature datalogger with an internal temperature sensor was used for measurements [6]. Typical graphs of temperature changes are shown in Fig. 1 - for room No. 4 and in fig. 2 - for room No.30.

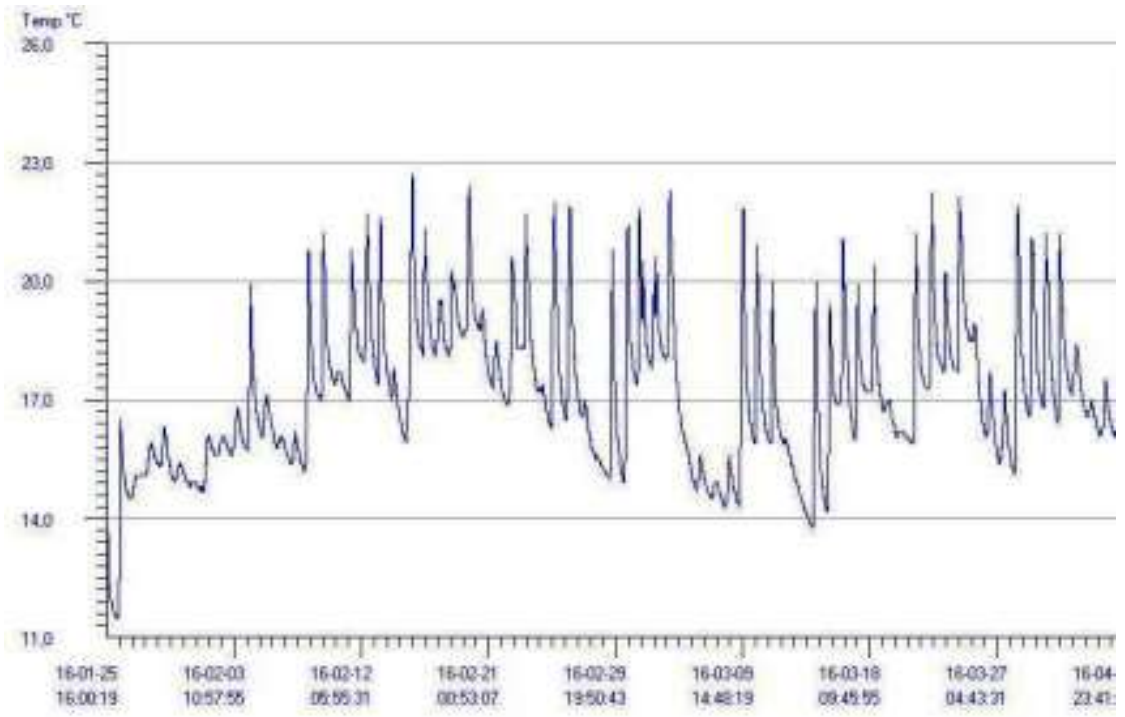

Fig.1. Temperature change in room No.4 of the educational building No.8

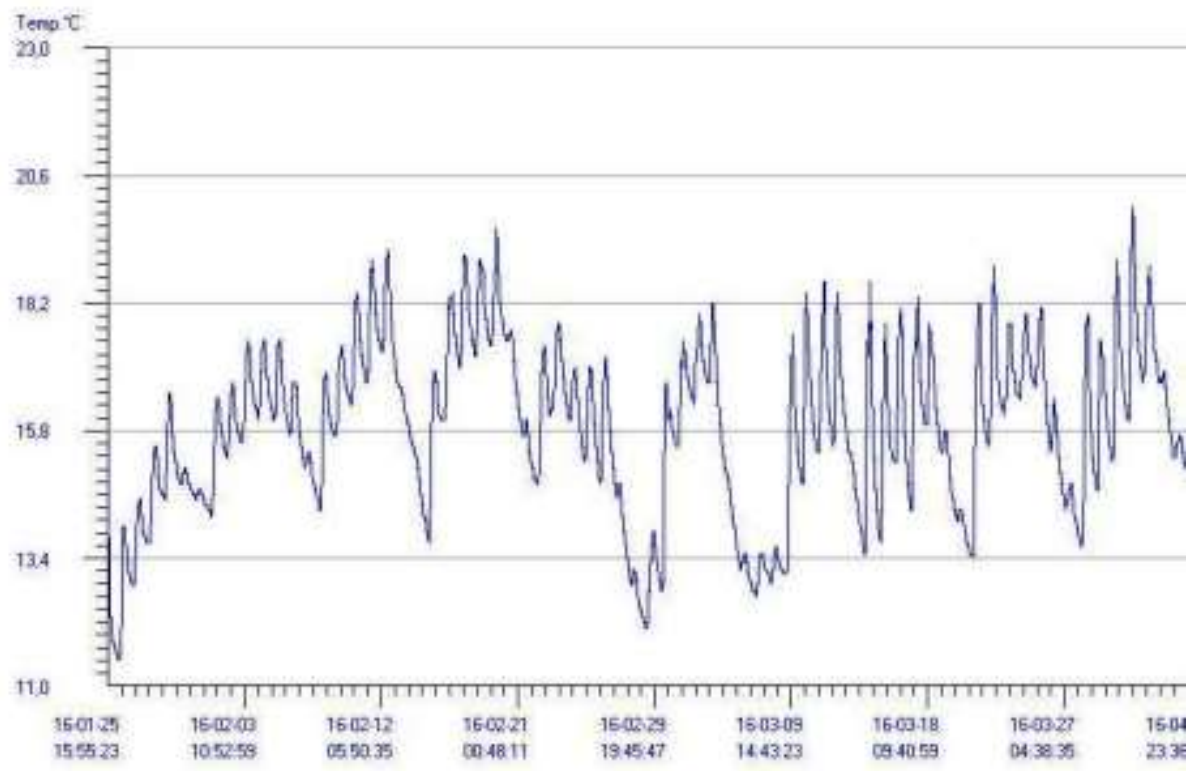

Fig.2. Temperature change in the room No.30 of the educational building No. 
It should be noted that these measurements took place after the completion of work for thermal modernization of the building, when the value of thermal resistance was brought to the standard, which contributed to the improvement of the thermal storage properties of the external enclosure and, as a result, the leveling of the internal air temperature profile both along the floors of the building and along the facades [6].

The analysis of the data obtained shows that if in room No. 4 (on the ground floor of the southern facade of the building) the temperature is on average $+18^{0} \mathrm{C}$, which corresponds to the standard value for classrooms, then in room No. 30 (on the second floor of the northern facade) the temperatures fluctuate around value $+15.8^{0} \mathrm{C}$, which is below the norm.

The temperature minimums on weekends are conditioned by automatic decrease in the heat load on heating at this time, which is carried out by the heating controller and RVD 115/109 controller, installed in the individual heating point of the building [6]. But an excessive decrease in temperature on February 28 and March 8 indicates a failure of the regulator settings.

\section{Conclusions and prospects.}

1. The main provision of the concept of studying the process of assessing and improving energy efficiency of energy consumption in campus buildings is its interpretation as a complex multi-parameter system.

2. The solution to the multifactorial task of increasing the efficiency of the complex system "heat source - man - building envelope" will contribute to the development of recommendations as for the reduction of the specific and total energy consumption in campuses of Ukraine's HEIs.

3. When implementing energy-saving measures, it is impossible to violate the conditions of comfort in rooms in which thermal equilibrium in the human body is maintained and there is no tension in its thermoregulation system. 


\section{References}

1. Batechko, N., Shelimanova, O., Shostak, S. (2020). Energy efficiency in Ukraine in the context of european practices: educational aspect. The Modern Higher Education Review, 4, 50-56. doi.org/10.28925/2518-7635.2019.4/6.

2. Tabunshchykov, Yu. A., Khromets, D. Iu., Matrosov, Yu. A. (1986). Teplovaia zashchyta ohrazhdaiushchykh konstruktsyi zdanyi y sooruzhenyi [Thermal protection of building envelopes and structures]. Moskow: Stroiyzdat, 380.

3. Mkhytarian, N. M. (2000). Enerhosberehaiushchye tekhnolohyy v zhylyshchnom y hrazhdanskom stroytelstve [Energy saving technologies in residential and civil construction]. Kyiv: Naukova dumka, 420.

4. Chupryna, Kh. M. (2014). Intehrovana yedyna enerhetychna model budivli [Integrated single energy model of the building]. Upravlinnia rozvytkom skladnykh system, 17, 125-131.

5. Ratushniak, H. S., Ratushniak, O. H. (2006). Upravlinnia proektamy enerhozberezhennia shliakhom termorenovatsii budivel [Management of energy saving projects through thermal renovation of buildings]. Vinnytsia: VNTU, 106.

6. Mishchenko, A.V., Shelimanova, O. V., Antypov, Ye. O. (2014). Analiz teplovoho komfortu $u$ prymishchenniakh navchalnoho korpusu №8 NUBiP Ukrainy pislia termomodernizatsii budivli [Analysis of thermal comfort in the premises of the educational building №8 NULES of Ukraine after thermal modernization of the building]. Naukovyi visnyk NUBiP Ukrainy, 194 (1), 119 - 123.

\section{МАТЕМАТИЧНЕ ЗАБЕЗПЕЧЕННЯ ЕНЕРГОЕФЕКТИВНОСТІ ТА КОМФОРТНИХ УМОВ В УСТАНОВАХ ВИЩОЇ ОСВІТИ УКРАЇНИ}

\section{Н. Г. Батечко, О. В. Шеліманова, С. В. Шостак}

Анотація. Актуальність підвищення енергоефективності будівель вітчизняних вищих навчальних закладів обумовлюється не тільки необхідністю заощадження енергоресурсів, а також і тим. що такі «зелені студмістечка» можуть стати основою для формування екологічного та енергоефективного способу життя сучасної молоді. Комплексний підхід до вибору енергозберігаючих заходів в будівлі вимагає таких моделей теплового комфорту, які враховують інтенсивність діяльності людини, тип одягу, швидкість руху повітря в кімнаті, відносну вологість тощฺо.

Мета дослідження - підвищення ефективності функиіонування енергетичної системи будівель університетського містечка иляхом врахування взаємодіі джерела енергії, системи опалення, теплозахисних властивостей огороджувальних конструкиій і нормованих параметрів мікроклімату приміщень.

Поряд з комплексним підходом до досліджуваної проблеми, з урахуванням необхідного комплексного аналізу енергозберігаючих заходів у системі «джерело теплоти - огороджувальні конструкиії - зовнішні параметри», має бути приділено увагу мікроклімату в приміщенні $i$ проблемі задоволення потреб людини в тепловому комфорті. 
"Енергетика і автоматика", №3, 2020 р.

За допомогою мініатюрного температурного даталогера $R C$ - $1 B$ здійснювався цілодобовий моніторинг температур в окремих приміщеннях навчального корпусу №8 НУБіП Украӥни протягом опалювального сезону.

Аналіз експериментальних даних показує, щуо незважаючи на поліпшення теплоакумулятівніх властивостей зовнішнього огородження будівлі після виконання робіт з термомодернізації, температури в приміщенні не завжди відповідають нормі.

Таким чином, при реалізації енергозберігаючих заходів не можна порушувати умов комфортності в приміщеннях, при яких зберігається теплова рівновага в організмі людини і відсутня напруга в його системі терморегуляиії.

Ключові слова: енергоефективність будівлі, багатофакторна математична модель, теплової комфорт

\section{МАТЕМАТИЧЕСКОЕ ОБЕСПЕЧЕНИЕ ЭНЕРГОЭФФЕКТИВНОСТИ И КОМФОРТНЫХ УСЛОВИЙ В УЧРЕЖДЕНИЯХ ВЫСШЕГО ОБРАЗОВАНИЯ УКРАИНЫ}

\section{Н. Г. Батечко, Е. В. Шелиманова, С. В. Шостак}

Аннотация. Актуальность повьшения энергоэффективности зданий отечественных высиих учебных заведений обуславливается не только необходимостью сбережения энергоресурсов, а также и тем. что такие «зеленые студгородки» могут стать основой для формирования экологического $u$ энергоэффективного образа жизни современной молодежи. Комплексный подход к выбору энергосберегающих мероприятий в здании требует таких моделей теплового комфорта, которые учитывают интенсивность деятельности человека, тип одежды, скорость движения воздуха в комнате, относительную влажность и тому подобное.

Цель данного исследования - повышение эффективности функичонирования энергетической системь зданий университетского городка путем учета взаимодействия источника энергии, системы отопления, теплозашитных свойств ограждающих конструкиий и нормируемых параметров микроклимата помещений.

Наряду с комплексным подходом $к$ исследуемой проблеме, с учетом необходимого комплексного анализа энергосберегающих мероприятий в системе «источник теплоть - ограждающчие конструкции - внешние параметры», долюно быть уделено внимание микроклимата в помещении и проблеме удовлетворения потребностей человека в тепловом комфорте.

$C$ помощью миниатюрного температурного даталогера $R C$ - 1 В осуществлялся круглосуточный мониторинг температур в отдельных помещениях учебного корпуса №8 НУБиП Украины в течение отопительного сезона.

Анализ экспериментальных данных показывает, что несмотря на улучшение теплоакумулятивних свойств наружного ограждения здания после выполнения работ по термомодернизации, температуры в помещуении не всегда соответствуют норме.

Таким образом, при реализации энергосберегающих мероприятий нельзя нарушать условий комфортности в помещениях, при которых сохраняется 
"Енергетика і автоматика", №3, 2020 р.

тепловое равновесие в организме человека и отсутствует напряжение в его системе терморегуляиии.

Ключевые слова: энергоэффективность здания, многофакторная математическая модель, тепловой комфорт 